\title{
SEPARABILITY OF OR OVERLAP BETWEEN PUBLIC POLICY AND PROCEDURAL GROUNDS FOR REFUSAL OF ENFORCEMENT OF FOREIGN ARBITRAL AWARDS UNDER THE NEW YORK CONVENTION
}

\section{Magdalena Inglot*}

\section{Introduction}

"Indeed, public policy in international commercial arbitration is a double-edged sword: helpful as a tool, dangerous as a weapon."

Public policy is the most frequently invoked grounds for refusal of enforcement of foreign arbitral awards. It should only be used in exceptional cases "as a shield to the enforcement of foreign awards which bear unwanted solutions." ${ }^{2}$ However, being a non-defined term, left to a subjective assessment of a court, public policy might also be a weapon, invoked as an excuse not to enforce arbitral awards.

The list of grounds for refusal of recognition and enforcement of foreign arbitral awards pursuant to the New York Convention on the

* Attorney, Regional Bar Council in Warsaw

1 L. Mistelis, "Keeping the Unruly Horse in Control" or Public Policy as a Bar to Enforcement of (Foreign) Arbitral Awards, 'International Law FORUM du droit international' 2000, vol. 2, at p. 248.

2 Ibid. 
Recognition and Enforcement of Foreign Arbitral Awards of $1958^{3}$ ("NYC") is exhaustive. Under the NYC, procedural defects are separate from public policy grounds for denial of recognition and enforcement of foreign arbitral awards. However, procedural defects are claimed ${ }^{4}$ by parties to be covered by public policy. In addition, state courts often identify procedural defects with violation of public policy. It seems that the same procedural irregularity may simultaneously fall under one of the procedural grounds and public policy. Potentially, it could result in the widening of the already broad scope of public policy.

This raises a question as to why the same procedural issues can be subject to different grounds for refusal and enforcement under the same regulations. Is it due to the significance of the aforementioned procedural principles that they require double protection? Or is the opposite true, and public policy does not cover procedural violations, at least not entirely? Only by answering these questions will it be possible to define the scope of procedural public policy. Thus, it is important to develop a concept of the relationship between public policy exception and procedural grounds for refusal of enforcement, as specified in the NYC.

Section II will address the general framework of public policy, which needs to be provided. Section III will constitute the basis for a thorough analysis of the connections between the procedural grounds for refusal of enforcement and public policy, under two different paragraphs of the same NYC Article V. Section IV will then consider any possible exceptions to the presented opinion on the separability of grounds for refusal of enforcement under the NYC. Section V will summarise the presented findings.

3 Convention on the Recognition and Enforcement of Foreign Arbitral Awards, opened for signature 10.6.1958, 330 UNTS 3 (entered into force 7.6.1959) (“NYC").

4 A. Jana, A. Armer, and J. Klein Kranenberg, Article V(1)(b), [in:] Herbert Kronke et al. (eds.), 'Recognition and Enforcement of Foreign Arbitral Awards. A Global Commentary on The New York Convention,' Wolters Kluwer, the Netherlands 2010, at pp. 1, 234-7 ("Recognition and Enforcement of Foreign Arbitral Awards"). 


\section{Public policy in international commercial arbitration}

\subsection{Public policy in the enforcement of foreign arbitral awards}

Parties submitting disputes to arbitration expect that the arbitral award will be binding and performed without any delay. However, if the losing party does not voluntarily carry out the award, the winning party may initiate an enforcement proceeding before a state court. Recognition ${ }^{5}$ and enforcement of foreign arbitral awards are governed by the NYC, which aims to facilitate the enforcement of foreign arbitral awards and limit the grounds for denial. This is known as the pro-enforcement bias of the NYC. ${ }^{6}$

The NYC imposes on the states that are parties to the NYC an obligation to recognise and enforce foreign arbitral awards, ${ }^{7}$ recommending that they should be considered final and binding. The finality of awards stems from the essence of arbitration, i.e. the freedom and autonomy of the parties. By agreeing on arbitration as a method of dispute resolution, parties also consent to be bound by the award and perform it voluntarily, without recourse to state courts, whose powers may be invoked in an enforcement proceeding initiated if a losing party fails to perform the award. State courts are entitled to either recognise and enforce arbitral awards or refuse doing so.

Recognition and enforcement may be refused in exceptional cases only. NYC Article $\mathrm{V}^{8}$ provides the exclusive grounds for refusal of enforcement, which should be construed narrowly. ${ }^{9}$ The grounds are contained in two paragraphs: NYC Article V (1) embodies, among others, procedural

5 This paper refers to the issues of the enforcement of foreign arbitral awards; however, the same rules apply to the recognition of foreign arbitral awards.

6 B. Hanotiau and O. Caprasse, Arbitrability, Due Process, and Public Policy under Article V of the New York Convention, 'Journal of International Arbitration' 2008, vol. 25, no 6 , at p. 721.

7 NYC Article III; see G. B. Born, International Commercial Arbitration, Wolters Kluwer, the Netherlands 2009, vol. 2, 2717.

8 NYC Article V.

$9 \quad$ J. D. Fry, Désordre Public International under the New York Convention: Wither Truly International Public Policy, 'Chinese Journal of International Law' 2009, vol. 8, no 1, at pp. 81, 94; D.F. Donovan, International Commercial Arbitration and Public Policy, 'N.Y.U. Journal of International Law and Politics' 1994-1995, vol. 27, at pp. 645, 649; L. Reed and J. Freda, Narrow Exceptions: A Review of Recent U.S. Precedent Regarding the Due Process and Public 
defects of the conduct of arbitration, ${ }^{10}$ while Article V (2) encompasses arbitrability ${ }^{11}$ and public policy. ${ }^{12}$

Public policy is regulated in NYC Article V (2)(b) ${ }^{13}$ which stipulates as follows:

Recognition and enforcement of an arbitral award may also be refused if the competent authority in the country where recognition and enforcement is sought finds that: (...) (b) The recognition or enforcement of the award would be contrary to the public policy of that country. ${ }^{14}$

Due to the fact that there is no legal definition of public policy, its scope is particularly broad. Interpretations of this term vary depending on the area of law to which it is applied and the nature of the values covered by it. In general, public policy encompasses essential norms of morality and justice. ${ }^{15}$ Despite its non-defined nature and broad scope, public policy ought to be interpreted narrowly and applied restrictively. ${ }^{16}$ In enforcement proceedings, public policy is used as a defence against introducing into the legal system of a state decisions which offend it.

\subsection{Domestic and international public policy}

Legal doctrine and jurisprudence distinguish between domestic and international public policy. ${ }^{17}$ This differentiation might be confusing since,

Policy Defenses of the New York Convention, 'Journal of International Arbitration' 2008, vol. 25, no 6, at pp. 649, 652-5.

10 Ibid. Article V (1).

11 Ibid. Article V (2)(a).

12 Ibid. Article V (2)(b).

13 NYC Article V (2)(b).

14 NYC Article V (2)(b).

15 Parsons \& Whittemore Overseas Co. Inc. v. Société Générale de l'Industrie du Papier (RAKTA), Bank of America, United States Court of Appeals, Second Circuit, 23.12.1974 reported in (1976) Yearbook Commercial Arbitration, vol. I, at p. 205.

16 Parsons \& Whittemore Overseas Co. Inc. v. Société Générale de l'Industrie du Papier (RAKTA), Bank of America, United States Court of Appeals, Second Circuit, 23.12.1974 reported in (1976) Yearbook Commercial Arbitration, vol. I, at p. 205.

17 Denis Coakley Ltd. v. Sté Michel Reverdy, Cour d'appel [Court of Appeal in Reims], 23.7.1981, reported in (1984) Yearbook Commercial Arbitration, vol. IX, at pp. 400-2; Adeline Chong, Transnational public policy in civil and commercial matters, 'Law Quarterly Review' 2012, vol. 128, at pp. 88-89. 
in a legal context, the term "international" usually relates to foreign laws and rules. However, in relation to public policy, the terms "domestic" and "international" both pertain to internal regulations, albeit of a slightly different character.

Domestic public policy comprises legal and moral rules that are enforceable in a given state. ${ }^{18}$ They apply to domestic awards only. ${ }^{19}$

International public policy has a narrower meaning. It is contained within the scope of domestic public policy and consists of the elements of a state's internal public policy that are essential to its justice system. ${ }^{20}$ As stated by the US Court, international public policy comprises the "fundamental principles of morality and justice of the state of the court." ${ }^{21}$ These principles are applicable not only to purely internal issues but also to matters with a foreign element. ${ }^{22}$ The role of international public policy is to protect the domestic legal system against the application of foreign rules or legal standards which could undermine the foundations of the system. ${ }^{23}$ It was accurately characterised by the Court of Appeal in Luxembourg, ${ }^{24}$ stating that:

According to the Convention [NYC], the public policy of the State where the arbitral award is invoked is thus not the internal public

18 M.A. Buchanan, Public Policy and International Commercial Arbitration, 'American Business Law Journal' 1988, vol. 26, at pp. 511-30; M. Rubino-Sammartano, International Arbitration Law and Practice, Kluwer Law International, $2^{\text {nd }}$ revised ed., the Netherlands 2001, p. 506; P. Lalive, Transnational (or Truly International) Public Policy, [in:] P. Sanders (ed.), 'Comparative Arbitration Practice and Public Policy in Arbitration,' ICCA Congress Series, 1986, at pp. 257-9.

19 H. Sikiric, Arbitration and Public Policy: Arbitration Proceedings and Public Policy, 'Croatian Arbitration Yearbook' 2000, vol. 7, at p. 85.

20 Hebei Import \& Export Corporation v. Polytek Engineering Company Limited, Court of Final Appeal of the Hong Kong Special Administrative Region, 9.2.1999 reported in (1999) Yearbook Commercial Arbitration, vol. XXIV, at p. 675.

${ }^{21}$ Parsons \& Whittemore Overseas Co. Inc. v. Société Générale de l'Industrie du Papier (RAKTA), Bank of America, United States Court of Appeals, Second Circuit, 23.12.1974, reported in (1976) Yearbook Commercial Arbitration, vol. I, at p. 205.

22 Hebei Import \& Export Corporation v. Polytek Engineering Company Limited, Court of Final Appeal of the Hong Kong Special Administrative Region, 9.2.1999, reported in (1999) Yearbook Commercial Arbitration, vol. XXIV, at p. 675.

${ }^{23}$ Sikiric, op. cit., at p. 85.

24 Kersa Holding Company Luxembourg v. Infancourtage, Famajuk Investment and Isny, Cour Supérieure de Justice [Court of Appeal in Luxemburg], 24.11.1993, reported in (1996) Yearbook Commercial Arbitration, vol. XXI, at pp. 617-26. 
policy of that country, but its international public policy, which is defined as being 'all that affects the essential principles of the administration of justice or the performance of contractual obligations' (Clunet 1977, 114), that is, all that is considered 'as essential to the moral, political, or economic order' (...). ${ }^{25}$

The distinction at issue was made regarding the concept of attaching different importance to mandatory rules applicable to domestic private law cases and private law cases related to one or more foreign legal systems. ${ }^{26}$ The standard of control and assessment should be different and less strict in cases containing international elements. This stems from the fact that not every mandatory domestic principle falls under international public policy. ${ }^{27}$ Thus, foreign awards do not have to comply with all mandatory provisions of the state of enforcement, but rather only those covered by international public policy.

The International Law Association in its Final Report on Public Policy ("Final ILA Report") made recommendations with respect to the application of international public policy and its narrow interpretation in enforcement proceedings. ${ }^{28}$ According to the Final ILA Report, international public policy consists of: (i) principles of justice and morality; ${ }^{29}$ (ii) rules preserving social, political, and economic interests of a state, ${ }^{30}$ and (iii) "the duty of the State to respect its obligations towards other States or international organisations." ${ }^{31}$

The differentiation and different roles of domestic and international public policy are also recognised by enforcement courts, which adopt a narrow interpretation of the scope of public policy in enforcement proceedings. $^{32}$

26

27

28 P. Mayer and A. Sheppard, Final ILA Report on Public Policy as a Bar to Enforcement of International Arbitral Awards, Report presented at International Law Association New Delhi Conference Committee on International Commercial Arbitration, New Delhi, 2002, at pp. 3-4 <http://www.newyorkconvention.org/publications/full-text-publications/ general/ila-report-on-public-policy-2002 > ("Final ILA Report").

29 Ibid, at p. 6.

30 Ibid.

31 Ibid.

32 German (F.R.) charterer v. Romanian shipowner, Bundesgerichtshof [Federal Court of Justice of Germany], 15.5.1986, reported in (1987) Yearbook Commercial Arbitration, 


\subsection{Substantive and procedural public policy}

NYC Article V (2)(b) ${ }^{33}$ uses the term "public policy" without differentiating between substantive and procedural. Such a distinction was introduced into the field of jurisprudence to determine the different types of norms covered by the public policy exception. ${ }^{34}$ Additionally, the distinction is made clear in the Final ILA Report. ${ }^{35}$ The substantive aspect relates to the merits of a tribunal's decision, while the procedural aspect refers to the procedure in which the award was rendered. ${ }^{36}$ Examples of violations of substantive public policy include the abuse of rights, discrimination, uncompensated expropriation, or abuse of principles of pacta sunt servanda and good faith. ${ }^{37}$ Partial arbitrators, fraud or corruption, breach of natural justice or "unequal footing in the appointment of the tribunal" ${ }^{38}$ constitute violations of procedural public policy.

Referring to procedural public policy, Fouchard stated that:

French public policy shall not recognise an arbitral award when it concerns a proceeding in which the basic requirements of justice have not been respected regarding the manner in which the proceedings were conducted. ${ }^{39}$

Fouchard recognised two main rights of the parties to arbitration under procedural public policy: the right to a defence, or to be heard in the adversarial proceeding, ${ }^{40}$ and the equality of the parties. ${ }^{41}$ The latter requires an arbitral tribunal to guarantee an equal opportunity for the

vol. XII, at pp. 489-91.

33 NYC Article V (2)(b).

34 Ch. Brunner, Procedural Public Policy as a Ground for Setting Aside International Arbitral Awards. Comments on the Swiss Federal Supreme Court's Decision of 28 April 2000 (Egemetal v. Fuchs; ATF 126 III 249), 'ASA Bulletin' 2000, vol. 18, no 3, at pp. 566, 569.

35 Final ILA Report, at pp. 6-7.

36 Final ILA Report, at p. 6.

37 Ibid.

38 Final ILA Report, at p. 7.

39 Sikiric, op. cit., at p. 85, quoting Philippe Fouchard, Droit International Privé, Paris 1996, p. 972.

40 E. Gaillard and J. Savage, Part 6: Chapter I - French Law, [in:] E. Gaillard and J. Savage (eds.), 'Fouchard Gaillard Goldman on International Commercial Arbitration,' Kluwer Law International, the Netherlands 1999, at p. 947.

41 Ibid. 
parties to present their arguments, without favouring one over the other. ${ }^{42}$ Each party must be given an opportunity to appoint an arbitrator. ${ }^{43}$ These principles are often defined as due process. ${ }^{44}$

\section{Separability of the grounds for refusal of enforcement under NYC Article V}

\subsection{Procedural irregularities under NYC Article V}

NYC Article V, apart from public policy, specifies different grounds for justifying refusal of enforcement of foreign arbitral awards. ${ }^{45}$ Some of the grounds for refusal listed in NYC Article V (1) are of a procedural character. These include (i) proper notice concerning the appointment of arbitrators or the arbitration proceedings and inability of the party to present its case (NYC Article V (1)(b) ${ }^{46}$ ) as well as (ii) inconsistencies between the composition of the arbitral tribunal or the arbitral procedure and the parties' agreement or the lex loci arbitri (NYC Article V (1)(d)). ${ }^{47}$

On the one hand, the NYC provides for specific procedural irregularities which may justify refusal of enforcement, but on the other, it also provides a broad and undefined ground for the refusal of public policy.

In order to justify the same procedural grounds for refusal of enforcement, parties usually invoke not only the circumstances of a procedural character, based on NYC Article V (1), but also public policy. ${ }^{48}$ It might be assumed from past cases that violations of procedural principles to some parties appear to be tantamount to public policy abuse, especially

42 Ibid, at p. 935.

43 Ibid.

44 Hanotiau and Caprasse, op. cit., at pp. 726-9; D. Otto and O. Elwan, Article V(2)

[in:] 'Recognition and Enforcement of Foreign Arbitral Awards', supra, at pp. 387-91.

45 NYC Article V.

$46 \quad$ NYC Article V (1)(b).

47 NYC Article V (1)(d).

48 Otto and Elwan, op. cit., at p. 365. 
in relation to due process. ${ }^{49}$ Moreover, even courts in cases of minor procedural irregularities consider infringement of public policy. ${ }^{50}$

This raises the question of what is the relation between public policy and other procedural grounds for refusal of enforcement, listed in NYC Article V (1). ${ }^{51}$

\subsection{Ex officio or on a motion of a party?}

The difference between circumstances listed in NYC Article V (1) and NYC Article V (2) lies in the manner in which they are taken into consideration by the court. The grounds for refusal under NYC Article V (1) have to be invoked by a party seeking refusal of enforcement in order to be considered by the court. On the other hand, the issues listed in NYC Article V (2), i.e. arbitrability (NYC Article V (2)(a)) ${ }^{52}$ and public policy (NYC Article V (2)(b)), ${ }^{53}$ are the only two defences which the court is obliged to consider in all cases of enforcing foreign arbitral awards, even if they are not invoked by the parties. The distinct manner in which the aforementioned defences are taken into account is significant.

Perhaps, procedural defects should not be recognised as part of public policy. If procedural infringements were to be considered ex officio, they would have been incorporated directly into NYC Article V (2) or as examples of public policy. The wording of NYC Article V (1) does not leave any doubt

49 Ibid, at pp. 387-91; Hanotiau and Caprasse, op. cit., at pp. 726-8; Not indicated (Syria) v. Not indicated, Hanseatisches Oberlandesgericht [Court of Appeal in Hamburg], 12.3.1998, reported in (2004) Yearbook Commercial Arbitration, vol. XXIX, at pp. 663-72; Company A (Japan) v. Company S (Germany), Company X (Germany), Oberlandsgericht [Court of Appeal in Thuringia], 8.8.2007, reported in (2008) Yearbook Commercial Arbitration, vol. XXXIII, at pp. 534-40.

50 Buyer (Austria) v. Seller (Serbia and Montenegro), Oberster Gerichtshof [Supreme Court of Austria], 26.1.2005, reported in (2005) Yearbook Commercial Arbitration, vol. XXX, at pp. 421-36; August Aasma et al. v. American Steamship Owners Mutual Protection and Indemnity et al., United States District Court, Northern District of Ohio, Western Division, 8.1.2003, reported in (2003) Yearbook Commercial Arbitration, vol. XXVIII, at pp. 1140-5; Shaanxi Provincial Medical Health Products I/E Corporation v. Olpesa, S.A., Tribunal Supremo [Supreme Court of Spain], 7.10.2003, reported in (2005) Yearbook Commercial Arbitration, vol. XXX, at pp. 617-22.

51 NYC Article V.

52 NYC Article V (2)(a).

$53 \quad$ NYC Article V (2)(b). 
that defects covered by this article have to be raised by the parties to be reviewed by the court. It suggests that it was conceived by the authors of the NYC that procedural irregularities under NYC Article V (1) should be separate from public policy. In such a case, public policy should not cover procedural violations referred to in NYC Article V (1). If invoked by the parties, they should not be regarded by the court under the public policy exception and only such procedural defects that are not covered by NYC Article V (1) could be considered as encompassed by public policy.

\subsection{Historical background}

The position against including the grounds of NYC Article V (1) in the scope of public policy is supported by a historical argument. In the first draft of the NYC, there was a single article listing the reasons for refusal of enforcement. ${ }^{54}$ Only following a proposal made by Germany, was the article divided into two separate paragraphs: ${ }^{55}$ one paragraph included the grounds taken into account only on request of a party, while the other provided for the grounds considered ex officio. ${ }^{56}$ At that time, no one argued that one of these paragraphs should be broad enough as to encompass the defences determined by the other. ${ }^{57}$

This concept seems to be in conformity with the prevailing opinion ${ }^{58}$ that the public policy exception should be interpreted narrowly. It can jus-

54 Report of the Committee on the Enforcement of International Arbitral Awards, E/AC. 42/4/Rev.1, UN ESCOR, 19 th sess., Agenda Item 14, UN Doc E/2704 (28.3.1955), annex II 2 <http://daccess-dds-ny.un.org/doc/UNDOC/GEN/N55/080/97/PDF/N5508097.pdf>.

55 Federal Republic of Germany, Consideration of the Draft Convention on the Recognition and Enforcement of Foreign Arbitral Awards. Federal Republic of Germany: amendments to Articles III to V to the draft Convention, United Nations Economic and Social Council at United Nations Conference on International Commercial Arbitration, Agenda Item 4, E/CONF.26/L.34 (28.5.1958) 1-2 <http://daccess-dds-ny.un.org/doc/UNDOC/LTD/ N58/127/18/PDF/N5812718.pdf >.

56 Ibid.

57 A.G. Maurer, The Public Policy Exception under the New York Convention. History, Interpretation, and Application, Juris, revised ed., New York 2013, p. 68.

58 J. van den Berg, Distinction Domestic-International Public Policy, [in:] 'New York Convention Consolidated Commentary Cases,' ICCA Yearbook, 1996, vol. XXI, at p. 502; Jan van den Berg, Refusals of Enforcement under the New York Convention of 1958: the Unfortunate Few, [in:] 'Arbitration in the Next Decade,' ICC Bulletin, Special Supplement 1999, at p. 86 . 
tify refusal of enforcement only in exceptional cases of egregious violation of norms. If procedural infringements constituting different grounds for such a refusal could be covered by public policy, its scope would broaden rather than become more restrictive.

\subsection{Burden of proof}

Arbitrability and public policy can be analysed by the court on the grounds of an arbitral award and arbitration agreement only. In relation to arbitrability, the court has to assess if an arbitral award was rendered in a case that can be resolved in arbitration under the law of the state of enforcement. In order to do so, only the relevant award and arbitration agreement must be analysed; ${ }^{59}$ other evidence or documents from the parties are not necessary. This is also the case in relation to public policy. For the court to analyse if the enforcement of the award is contradictory to public policy needs, it only needs to review the award, with no other information from the parties being required. Thus, only arbitrability and public policy can be invoked by the court on its own motion. It is also compatible with NYC Article IV (1), under which a party applying for an enforcement of an arbitral award is obliged to present the court with both the award and arbitration agreement. ${ }^{60}$

If public policy was to encompass procedural defences referred to in NYC Article V (1), the court would have to analyse other information and documents, with the exception of the arbitral award and arbitration agreement. Thus, public policy could not be taken into account ex officio, and a review of the procedural defences under public policy could be performed only with the parties' cooperation. The wording of NYC Article V (2) proves that such was not the intention of the drafters of the NYC. The court must be able to assess compatibility with public policy on the basis of the award only. Hence, the distinction of public policy and arbitrability from other grounds for refusal in NYC Article V was intentional. Including procedural defences under the public policy exception would unjustifiably change the legal structure and character of this Article.

On the other hand, the analysis of the arbitral award and arbitration agreement is not sufficient to assess the grounds for refusal of enforcement

59 NYC Article IV.

60 NYC Article IV. 
that are listed in NYC Article V (1). It stems from the wording of this article, which requires a defendant to submit proof to challenge the enforcement. The court is not allowed to deny enforcement if a party fails to prove the existence of one of the grounds provided for in NYC Article V (1). ${ }^{61}$ Even if the court itself recognises procedural irregularities in the conduct of arbitration, it is not entitled to act upon them without the party's demand. ${ }^{62}$ This is so even with respect to irregularities that - if raised by the party would account for refusal of enforcement.

A different interpretation would shift the burden of proof onto the court, changing the general rule on presenting evidence. ${ }^{63}$ It follows that it is not the role of the court to substitute for the party in proving procedural irregularities, where the party failed to do so.

\subsection{Lex specialis derogat legi generali}

Accepting that NYC Article V (2)(b) covers procedural grounds listed in NYC Article V (1) would be contradictory to the general principle of lex specialis derogat legi generali. ${ }^{64}$ It is commonly accepted that if there are specific principles, they should be applied, instead of more general regulations on the same issue. In cases where other procedural grounds might be invoked to substantiate a denial of enforcement, public policy should not be recognised by the court as covering these grounds.

\section{6. "May also be refused" 65}

Public policy should constitute a reason for refusal of enforcement if other grounds from NYC Article V are not met. ${ }^{66}$ This derives from the wording of NYC Article V (2), which states that enforcement "may also be

61 Maurer, op. cit., p. 68.

62 Ibid.

63 Ibid.

64 See Chrome Resources S.A. v. Léopold Lazarus Ltd., Tribunal Fédéral [Federal Supreme Court of Switzerland], 8.2.1978, reported in (1986) Yearbook Commercial Arbitration, vol. XI, at p. 539.

65 NYC Article V (2).

66 Maurer, op. cit., p. 69. 
refused." ${ }^{\prime 67}$ In that sense, public policy can be regarded as a subsidiary ${ }^{68}$ principle or a tool of "a last resort." "It is always reviewed by the enforcement court but may constitute a ground for refusal of enforcement only if other circumstances raised by a party are not substantiated. Public policy might be taken into consideration, exceptionally, in cases which present the most egregious violations of the legal system of the state of enforcement. ${ }^{70}$ This is because NYC Article V (2)(b) does not cover all possible violations, not even all that are incorporated into the remaining Articles. ${ }^{71}$ Otherwise, the list of infringements under NYC Article V (1) would lack any sense. ${ }^{72}$ This was confirmed by the Federal Supreme Court of Switzerland, which held that "(...) the regularity of the proceedings must in the first place be ascertained in light of Article $\mathrm{V}(1)$ and only subsidiarily from the point of view of internal public policy." ${ }^{73}$

\subsection{The law "of that country" 74}

The difference between the qualifying procedural irregularities under NYC Article V (1) and NYC Article V (2)(b) is not merely a matter of wording or theoretical debate. It has important practical implications.

The court assesses a possible violation of public policy in accordance with the law "of that country,"75 meaning the law of the state where the enforcement is sought. Public policy of the lex loci arbitri is of no relevance. ${ }^{76}$ Procedural infringements under NYC Article V (1)(b) ${ }^{77}$ and NYC Article V

67 NYC Article V (2)(b).

68 Chrome Resources S.A. v. Léopold Lazarus Ltd., Tribunal Fédéral [Federal Supreme Court of Switzerland], 8.2.1978, reported in (1986) Yearbook Commercial Arbitration, vol. XI, at p. 539.

69 Otto and Elwan, op. cit., at p. 365.

70 Maurer, op. cit., p. 69.

71 Ibid.

72 Ibid.

73 Chrome Resources S.A. v. Léopold Lazarus Ltd., Tribunal Fédéral [Federal Supreme Court of Switzerland], 8.2.1978, reported in (1986) Yearbook Commercial Arbitration, vol. XI, at p. 539.

74 NYC Article V (2)(b).

75 NYC Article V (2)(b).

76 Otto and Elwan, op. cit., at p. 369.

77 The law applicable to due process under NYC Article V (2)(b) is subject to debate. The author is of the opinion that lex loci arbitrii or the law governing the conduct of 
(1)(d) may be considered in relation to the law of the state of arbitration ${ }^{78}$ and law applicable to arbitration proceedings agreed by the parties. ${ }^{79}$ These laws might not be the laws of the same country. In fact, they are the same only when enforcement is sought in the state of the seat of arbitration; however, in international commercial arbitration, this is not a rule. In many cases, parties choose a place which they have no connection with for the seat of arbitration. ${ }^{80}$ It is neither the state of residence of either party nor are their assets located there.

Thus, the law applicable for arbitration proceedings is usually different from the procedural law of the state of enforcement. Assuming that procedural irregularities might simultaneously fulfil one of the requirements of NYC Article V (1) and public policy under NYC Article V (2)(b), their analysis on these two grounds might lead to completely different results. This is due to the fact that different laws may be applicable under the aforementioned paragraphs of the NYC.

The same situation which under lex loci arbitri constitutes one of the irregularities falling under NYC Article V (1) might be admissible by public policy rules of the state of enforcement and, vice versa, certain procedural irregularities which are permissible under lex loci arbitri might be incompatible with the public policy of the state of enforcement.

It seems that the analysis of the same procedural situation on the grounds of the same case should not amount to contradictory judgments of enforcement or refusal, depending on the law applicable to its review.

arbitration (if it is different than lex loci arbitrii) applies to potential violations of due process. Such violations should not be analysed from the perspective of procedural law of the state of enforcement. This would require application of procedural rules of this state in arbitration. Arbitrators should not be expected to foresee in which countries a future award might be enforced and apply the procedural rules of such states in arbitration. For different opinions see Jana, Armer and Kranenberg, op. cit., at pp. 237-40; Born, op. cit., pp. 2740-60; N. Blackaby et al. (eds.), Redfern and Hunter on International Arbitration, Oxford University Press, $5^{\text {th }}$ ed., Oxford 2009, p. 644.

78 P. Nacimiento, Article V (1)(d), [in:] 'Recognition and Enforcement of Foreign Arbitral Awards,' op. cit., at pp. 287-8.

$79 \mathrm{~W}$. Ma, Recommendations on public policy in the enforcement of arbitral awards, 'Arbitration' 2009, vol. 75, no 1, at p. 14. In most cases, the procedural law governing the conduct of arbitration is the law of the seat of arbitration; however, it cannot be excluded that these laws would be the laws of different countries. For the purpose of this paper, the author made the assumption that the law of the seat of arbitration applies to the conduct of arbitration.

80 Blackaby et al. (eds.), op. cit., p. 630. 
This would generate inconsistencies in the application of the law on the enforcement of foreign arbitral awards.

\subsection{Substantive issues only}

NYC Article V (2) was intended to deal with substantive issues. ${ }^{81}$ Only this type of violation can be found by the court by merely reading the award without any input from the parties. ${ }^{82}$ As mentioned above, to assess procedural irregularities, the court needs to analyse additional information and documents provided by the parties. The assessment of due process or impartiality and independence of arbitrators cannot be performed without notes, summaries, or protocols from the hearings.

Doubts may be raised as to the ability of procedural irregularities to violate public policy. Under NYC Article V (2)(b), it is neither the award nor arbitration procedure but rather the enforcement of the award that has to violate public policy in order to justify refusal of enforcement. ${ }^{83}$ The court should not decide whether the award violates public policy; its review is narrower, ${ }^{84}$ as it has to determine if the result of enforcement would infringe public policy. ${ }^{85}$ Violations of procedural rules, or even substantive law, may occur in the course of arbitration proceedings without having any effect on the enforcement of the award. It is beyond dispute in the legal doctrine that the enforcement of the award might violate substantive public policy in the state of enforcement. ${ }^{86}$ This is a case of an award obliging a party to perform criminal acts or acts that might constitute a breach of essential principles of public law, penalised in the state of enforcement. ${ }^{87}$

Moreover, arbitrability, the second ground for refusal of enforcement listed in NYC Article V (1)(a), ${ }^{88}$ also has a substantive legal character. It is the substantive law of the enforcement state that is decisive in determining

81 Maurer, op. cit., p. 68.

82 Ibid.

83 NYC Article V (2)(b).

84 Kersa Holding Company Luxembourg v. Infancourtage, Famajuk Investment and Isny, Cour Superieure de Justice [Court of Appeal in Luxemburg], 24.11.1993, reported in (1996) Yearbook Commercial Arbitration, vol. XXI, at pp. 617-26.

85 Otto and Elwan, op. cit., at pp. 365-6.

${ }^{86}$ Brunner, op. cit., at p. 569; Final ILA Report, pp. 5-7.

${ }_{87}$ Maurer, op. cit., p. 70.

88 NYC Article V (2)(a). 
which disputes are reserved for the state courts' adjudication. Even if, upon the parties' agreement, were these types of cases submitted to arbitration, the arbitral award would not be enforced. Non-arbitrable issues represent the most significant interests of the country, which have to remain under its control in order to be protected.

The above reasons prove that the purpose behind dividing NYC Article $\mathrm{V}$ into two paragraphs was to separate the substantive norms protecting the foundations of the legal system of the state and its most important interests from procedural rules and parties' rights in arbitration.

\subsection{Party autonomy}

Taking into account procedural defects, ex officio might contradict one of the foundations of arbitration, i.e. the party autonomy. The consent of the parties to submit a dispute into arbitration subject to certain procedural rules, a particular mechanism of arbitrators' appointment, or arbitration institution, indicates that such was their will. Hence, these rules should not be put into question by the enforcement court if the parties themselves do not challenge procedural defects or particular acts of the tribunal. For instance, should the parties decide to appoint an unqualified arbitrator or to have a sole arbitrator chosen by one party if another party fails to appoint its arbitrator in a particular time, their agreement in this regard should be respected.

The court itself has not been authorised by the parties to analyse these issues ex officio. If the parties do not treat certain acts of the tribunal as violations of procedural rules, they should not be considered as such by the court. In this sense, NYC Article V (1) protects a party's autonomy in determining the rules of the conduct of arbitration, which cannot be challenged by the court unless at the party's request. ${ }^{89}$ Furthermore, the party has to empower the court to adjudicate procedural irregularities by furnishing proof of particular procedural violations. ${ }^{90}$

Taking the above into consideration, the procedural defects listed under NYC Article V (1) should constitute a distinct group of grounds for refusal of enforcement, separate from the public policy exception under NYC Article V (2)(b). Procedural infringements ought to be directly 
invoked by the parties to be considered by the court, which should not address them ex officio. There would be no point in providing two separate grounds for refusal of enforcement under two paragraphs of NYC Article $V$ if procedural violations falling under NYC Article V (1) were covered by the public policy exception. NYC Article V (1) would be of no importance in relation to procedural violations if all of them were encompassed by the broader defence of public policy. Consequently, the public policy exception should only be used in cases which do not meet the requirements of the other grounds referred to in NYC Article V.

\section{Exceptions}

\subsection{Protection of the integrity of a state's legal system}

If a party fails to raise procedural infringements, based on one of the grounds of NYC Article V (1), there should be no reason for the court to take them into account ex officio. The narrow interpretation of public policy and its application to exceptional cases of egregious violations support the separation of procedural defences embodied in NYC Article V (1) from public policy. To protect the efficiency of arbitration and finality of the awards, on the one hand, and the most essential principles of the state of enforcement on the other, public policy has to be applied restrictively to any procedural irregularities challenged by the party to enforcement proceedings, as the violation of public policy has to be approached by the court with reserve.

Nevertheless, there are situations where an intervention of a state's judicial body into the outcome of arbitration is unavoidable and even required. The impartiality and independence of a judicial body, the right of the parties to be heard, present their arguments, and participate in a tribunal's hearings are elements of public policy in most legal systems. ${ }^{91}$ Legal procedure based on fairness and justice constitutes a foundation not only of a legal system but also of a state itself. Preserving the finality of an arbitral award and pro-enforcement policy should not outweigh the most essential principles of the state's justice.

91 R. Wolff, Article V (2)(b), [in:] R. Wolff (ed.), 'New York Convention on the Recognition and Enforcement of Foreign Arbitral Awards of 10 June 1958. Commentary,' C.H. Beck, Freiburg 2012, at pp. 419-25. 
The question arises as to what the enforcement court should do if significant procedural defects have not been raised by a party based on one of the grounds of NYC Article V (1). Should the court ignore the defects, as they have not been protested by a party? The application of the separability of the grounds for refusal of enforcement under NYC Article V would amount to such a result.

Perhaps, as an exception, the court should take the aforementioned procedural defects into account ex officio, as a violation of public policy. Disregarding the gravest procedural defects in the name of protecting the finality of the award and separability of the grounds under NYC Article V may result in damaging the integrity of a legal system. Its principles may be undermined by an award rendered in a proceeding burdened with severe irregularities. It seems that, in such situations, it is justifiable to use public policy ex officio to refuse the enforcement of the award. ${ }^{92}$

Moreover, excluding all the grounds under NYC Article V (1) from the scope of public policy would result in the non-existence of procedural public policy in some states, as its elements would be totally encompassed by NYC Article V (1).

Thus, in exceptional cases, it is acceptable that the court of the state of enforcement takes into account procedural defects, even those covered by one of the grounds in NYC Article V (1), as a violation of public policy under NYC Article V (2)(b). However, this is not a rule applicable to any case of procedural irregularities embodied in NYC Article V (1). The enforcement court should thoroughly analyse the circumstances of every case and apply public policy to procedural defects listed in NYC Article V restrictively. For such defects to be encompassed by the public policy exception, they have to meet certain conditions, as explained below.

92 See Not indicated v. Not indicated, Bezirksgericht [Court of First Instance in Affoltern am Albis], 26.5.1994, reported in (1998) Yearbook Commercial Arbitration, vol. XXIII, at pp. 754-63; Rice Trading (Guyana) Ltd. v. Nidera Handelscompagnie BV, Gerechtshof [Court of Appeal in the Hague]; President, Arrondissementsrechtbank [Court of First Instance in Rotterdam], 28.4.1998, reported in (1998) Yearbook Commercial Arbitration, vol. XXIII, at pp. 731-4; G.W.L. Kersten \& Co. B.V. v. Société Commerciale Raoul-Duval et Cie, Gerechtshof [Court of Appeal in Amsterdam], 16.7.1992, reported in (1994) Yearbook Commercial Arbitration, vol. XIX, at pp. 708-9. 


\subsection{Fundamental principles}

Not every erroneous application of procedural rules is sufficient to be covered by the scope of public policy and justify a denial of enforcement. This is not only due to different laws applicable to arbitration proceedings and issues with determining the scope of public policy, but also to the fact that public policy cannot cover every procedural irregularity, which is related to the nature of legal norms.

Procedural issues falling under one of the grounds of NYC Article V (1) may constitute a violation of public policy only in cases of infringements of fundamental principles. ${ }^{93}$ Only the fundamental character of procedural principles may justify their consideration ex officio by the court of the state of enforcement. As emphasised by the Swiss Supreme Court, this is due to the fact that they guarantee an independent proceeding, addressing claims and allegations raised by the parties, based on fairness and justice and conducted in accordance with the applicable procedural norms. ${ }^{94}$ In the Court's opinion, a violation of procedural public policy occurs only in the case of infringement of fundamental, generally recognised and accepted procedural norms "(...) whose non-compliance would bring about an unbearable contradiction with the sense of justice, so as to make the award incompatible with legal and moral fundamental principles recognised in civilised nations." ${ }^{95}$

To refuse the enforcement of an arbitral award on the grounds of the abuse of procedural public policy, the court is obliged to determine that the infringed norms lie in the core of judicial process. This is exemplified by the opinion of the Swiss Supreme Court, which stated that the provision from the Terms of Reference under which "the parties shall in any case have an opportunity to express themselves orally before the arbitral tribunal takes its decision" ${ }^{16}$ is not as fundamental as to affect the party's right to be heard. ${ }^{97}$

93 Egemetal Demir Celik Sanayi ve Ticaret A.S. v. Fuchs Systemtechnik GmbH, Bundesgericht [Federal Supreme Court of Switzerland], 28.4.2000, reported in (2000) ASA Bulletin 18(3), at pp. 558-65 ("Egemetal v. Fuchs").

94 Ibid; Brunner, op. cit., pp. 569-70.

95 Ibid, p. 570.

96 U. v. Epoux G., Bundesgericht [Federal Supreme Court of Switzerland], 11.7.1991, quoted in Brunner, op. cit., p. 569.

97 Brunner, op. cit., p. 569. 
Thus, the mere infringement of general procedural rules applicable to arbitration does not amount to a violation of public policy. The grounds listed in NYC Article V (1) do not violate public policy through their procedural character alone. They may be encompassed by NYC Article V (2) (b) only in exceptional situations of infringements of the most essential principles. Furthermore, even if some acts of the tribunal violate the law applicable to arbitration or parties' rights are not fully respected, it does not constitute an infringement of the procedural law of the state of enforcement per se, nor does it, by itself, violate public policy.

In most cases, only serious violations of due process embodied in NYC Article V (1)(b) ${ }^{98}$ can simultaneously constitute a violation of public policy. Other procedural irregularities, regarding the composition of the arbitral tribunal or the procedure itself being at variance with the parties agreement (NYC Article V (1)(d)), ${ }^{99}$ usually do not contradict public policy.

\subsection{Egregious violations}

Not every infringement of procedural fundamental principles of the state of enforcement can constitute a violation of public policy amounting to denial of enforcement of an arbitral award. Such infringement has to be egregious, severe, and obvious. These characteristics focus not on the values protected by norms or the types of norms constituting public policy but on the manner in which they have been violated. This was explained in detail by the Swiss Court, which held that "(...) procedural public policy is only violated if such essential procedural principles are at issue whose disregard amount to an unbearable contradiction with the sense of justice under the Swiss lex fori." ${ }^{100}$ Only such public policy contradictions that are egregious and self-evident can corroborate refusal of enforcement.

98 NYC Article V (1)(b).

99 NYC Article V (1)(d).

100 United Financial Group v. Warmbrunn, Bundesgericht [Federal Supreme Court of Switzerland], 26.10.1977, cited in Brunner, op. cit., p. 574 (emphasis added). 


\subsection{State - interest approach}

The differentiation between the two paragraphs of NYC Article V listing different types of grounds for challenging the enforcement of arbitral awards determines different values and interests which are protected by these paragraphs. It also provides for a different approach of the court to analysing grounds for refusal and enforcement.

An analysis of the grounds listed in NYC Article V (1)(b) and (d) in enforcement proceeding is undertaken from the perspective of a party. These defences constitute mostly procedural rights and guarantees of the parties to arbitration. Thus, pursuant to NYC Article V (1), they should be taken into account by the court upon a party's request. A party should benefit from an independent adjudication process conducted in accordance with the applicable procedural law. If procedural irregularities occur or party's guarantees are not respected, it is entitled to raise them in the course of enforcement proceedings under NYC Article V (1).

An analysis of the grounds of NYC Article V (2) is performed from a different perspective. Arbitrability and public policy protection go deeper than procedural guarantees. These principles protect not only the individual rights of a party but also the state's most vital interests. Their role is to prevent an arbitral award contradicting such principles from having any effect on the state's legal system.

Thus, even an analysis of the same procedural defects may amount to different results, depending on the approach assumed. As already stated, procedural defences falling under NYC Article V (1) may be considered by the court as public policy in exceptional situations. Only egregious violations of fundamental principles may justify their analysis on the grounds of public policy. However, such an assessment should be performed from the perspective of a state's interest rather than a party's rights.

Public policy requires the court to determine if an arbitral award contradicts essential and mandatory norms of a state. ${ }^{101}$ The court is allowed to refuse the enforcement of an award only if it endangers the integrity of the legal system. Even in these exceptional cases, when the court is allowed to take the grounds listed in NYC Article V (1) into account ex officio, it should analyse them from a state perspective only.

101 See Not indicated v. Not indicated, Bezirksgericht [Court of First Instance in Affoltern am Albis], 26.5.1994, reported in (1998) Yearbook Commercial Arbitration, vol. XXIII, at pp. 754-63. 


\subsection{Impact of a procedural violation on the final result of the case}

In cases of a violation of substantive law, enforcement can only be refused if a causal nexus exists between the violation and the decision in the case. The enforcement court has to make a two-step analysis. Firstly, it needs to assess if the allegedly violated legal norm or principle constitutes an element of substantive public policy in the state of enforcement. And secondly, if the result of a particular case also infringes the public policy of that state. Thus, the court has to determine if the violation had any impact on the final decision in the case. ${ }^{102}$

The question arises if the same requirement of a causal relationship pertains to procedural public policy. In this regard, the Court of Appeal in Hamburg presented the following view:

The violation could not be cured by the fact that the arbitral decision would not have been different if there had been a fair trial. The Court of Appeal stated that a violation is present as soon as it cannot be excluded that a hearing [of the German firm] could have led to a more favourable decision [for the German firm]. ${ }^{103}$

If a procedural violation does not have any impact upon the final ruling then, perhaps, it should not constitute grounds for refusal. The excerpt from a judgment, quoted above, is self-contradictory. On the one hand, once a violation occurs, it cannot be excluded that the court's decision might have been different (more favourable to the losing party) if all the requirements of a fair trial had been met. On the other hand, even if the final decision could not have been different, there would still be a violation of a fair trial, amounting to refusal of enforcement. Where should the line be drawn to distinguish between a violation of a right and a violation of a right amounting to a denial of enforcement?

The real impact of a procedural infringement on the outcome of arbitration was emphasised by the German Federal Court of Justice. ${ }^{104}$ It held

102 Brunner, op. cit., pp. 570-1.

103 Firm P v. Firm F, Oberlandesgericht [Higher Regional Court in Hamburg], 3.4.1975, reported in (1977) Yearbook Commercial Arbitration, vol. II, at p. 241.

104 German (F.R.) charterer v. Romanian shipowner, Bundesgerichtshof [Federal Court of Justice of Germany], 15.5.1986, reported in (1987) Yearbook Commercial Arbitration, vol. XII, at pp. 489-91. 
that “(...) the recognition of an arbitral award can generally only be denied in those cases where the violation of the duty of impartial administration of justice had a real impact on the arbitral proceedings." 105

This decision was rendered in relation to the impartiality of the sole arbitrator, as one of the values encompassed by the procedural public policy. However, the Court spelled out the general rule on causal nexus.

An even more restrictive approach was presented by the High Court of New Zealand, which held that a party is obliged to demonstrate a strong causal connection between the alleged breach of natural justice being covered by the procedural public policy and the outcome of the case. ${ }^{106}$ Only infringements which have an impact on the tribunal's decision may justify refusal of enforcement.

On the other hand, the Federal Supreme Court of Switzerland presented a contradictory view. Referring to the denial of justice and the parties' right to be heard, the Court determined that the causal connection between a violation of public policy and the final decision in a case is not a requirement in relation to fundamental procedural norms; this is because:

(...) [their] rationale is not to assure through the challenge procedure a - according to the Court's limited scope of review - 'correct' decision on the merits, but to make sure that the parties may benefit from an independent adjudication of the relief sought and submitted in compliance with the applicable procedural rules. ${ }^{107}$

Only through fair and just procedure is the tribunal able to reach a correct decision based on the merits. The analysis of substantive law is based on the determination of facts, which is governed by procedural rather than substantive rules. Any violation of procedural law or an erroneous decision concerning the conduct of arbitration may have an impact on the final outcome of a case. It depends on a norm being violated and the character of the violation. Every situation has to be assessed in the context of a particular case. Thus, arriving at a general conclusion that irregularities forming procedural public policy do not need to impact the final decision to justify refusal of its enforcement is excessive, especially

105 Ibid.

106 Downer-Hill Joint Venture v. Government of Fiji (2005) 1 NZLR 119.

107 Brunner, op. cit., p. 571, citing the case Not Indicated v. Not Indicated, 1. Zivilabteilung [ $1^{\text {st }}$ Civil Division], 25.4.1995, reported in (1995) 13 (4) ASA Bulletin, at pp. 708-10. 
in relation to the enforcement of arbitral awards, which should only be denied in exceptional circumstances.

Only if there is a possibility that procedural violations might have impacted the final decision may refusal of enforcement be justified. It is indisputable that fundamental procedural rights and parties' guarantees aim at assuring an independent adjudication mechanism. The enforcement court needs to be particularly cautious in assessing their potential violations in light of the specific circumstances of a case. However, in some instances, it is self-evident that even a departure from the rules, has not affected the tribunal's findings. There is no reason why the court should deny the enforcement of an award if procedural defects have not affected the final outcome of the arbitration, and the tribunal would have reached the same decision even if all the procedural guarantees had been met.

\subsection{Waiving the right to challenge procedural violations}

Violations falling under NYC Article V (1) may be invoked in enforcement proceedings upon a party's motion or, exceptionally, ex officio. However, in some cases a party may be devoid of the right to challenge certain procedural irregularities, even if they could be covered by the public policy exception otherwise.

A party is obliged to inform the arbitral tribunal and another party about any procedural irregularities or defects raising doubts as to their compliance with the applicable law. Objecting to procedural irregularities has to be done without any delay once a party learns about the grounds for a challenge. ${ }^{108}$

If the party fails to do so, it may forfeit the right to raise these issues at the stage of enforcement. As emphasised in the legal doctrine, "It is a manifest abuse of the law not to invoke certain grounds for challenge and to hold them 'in reserve,' so as to put them forth later on in the event of an unfavourable result of the proceedings." ${ }^{109}$ Challenging procedural violations immediately is required by the principle of good faith.

In practice, this obligation usually occurs in relation to the impartiality and independence of arbitrators. The German Federal Court of Justice held that challenging arbitrators' partiality on the grounds which became

Ibid. 
known to the party before or during arbitration is possible in the course of arbitration proceeding only. ${ }^{110}$ If a party fails to challenge these irregularities in arbitration, it is deprived of the possibility to question them in enforcement proceedings. ${ }^{111}$ In Egemetal v. Fuchs, the Swiss Court held that the plaintiff waived its right to challenge the award. The plaintiff failed to inform the tribunal and the opposing party about the grounds to challenge a lack of independence of the expert immediately after the doubts arose. ${ }^{112}$ A similar approach was taken by the US Court of Appeals. ${ }^{113}$ It held that the defendant's failure to challenge the arbitrator's lack of impartiality and corruption might result in a party's waiver to raise these issues under the public policy defence in enforcement proceedings. ${ }^{114}$ Likewise, the Supreme Court of Hong Kong refused to accept an incorrect composition of the arbitral tribunal. The defendant - by not invoking this issue in arbitration - waived its right to do so in enforcement proceedings. ${ }^{115}$

Thus, if a party could have objected to procedural violations in arbitration but failed to do so, it forfeited the right to raise these defects either under one of the grounds of NYC Article V (1) or NYC Article V (2) (b). Moreover, the court should not take such violations into account $e x$ officio. This is confirmed by the Final ILA Report, according to which, a party may not rely on a violation of fundamental principles of public policy if it failed to object to such a violation in arbitration. ${ }^{116}$ The only exception is the party's unawareness of an infringement at the time of arbitration or if a party "was otherwise prevented from raising it with the tribunal." ${ }^{\text {"117 }}$

110 Shipowner v. Cattle and meat dealer, Bundesgerichtshof [Federal Court of Justice of Germany], 1.2.2001, reported in (2004) Yearbook Commercial Arbitration, vol. XXIX, at p. 713.

111 Ibidem.

112 Egemetal Demir Celik Sanayi ve Ticaret A.S. v. Fuchs Systemtechnik GmbH, Bundesgericht [Federal Supreme Court of Switzerland], 28.4.2000, reported in (2000) ASA Bulletin 18(3), at pp. 558-65.

113 AAOT Foreign Economic Association (VO) Technostroy Export v. International Development \& Trade Services Inc, 139 F 3d 980 ( $2^{\text {nd }}$ Cir., 1998).

114 Ibid.

115 China Nanhai Oil Joint Service Corporation Shenzhen Branch v. Gee Tai Holdings Co. Ltd., Supreme Court of Hong Kong, High Court, 13.7.1994, reported in (1995) Yearbook Commercial Arbitration, vol. XX, at pp. 671-80.

116 Final ILA Report, at p. 9.

117 Final ILA Report, at pp. 9-10. 
It cannot be denied that not all procedural guarantees may be waived, while some may be waived only to an extent. ${ }^{118}$ However, the court has to analyse such issues in light of particular circumstances of a case, as enforcement cannot amount to injustice. At the same time, contrary to some opinions in the legal doctrine, the sole fundamental nature of rights and guarantees cannot by itself justify the stance that they cannot be waived. ${ }^{119}$ The negligence of a party to raise violations of fundamental rights in arbitration may amount to a waiver of the right to challenge these defects in enforcement proceedings.

\section{Conclusions}

Public policy remains one of the most complex issues in international commercial arbitration. Many relevant opinions presented in the legal doctrine prove a great significance of public policy for enforcement proceeding. Preserving or undermining the outcome of arbitration depends on a proper application of the public policy exception. Thus, its interpretation and apprehension of its scope is of the essence.

In addition, defining procedural public policy and its relation towards other procedural defences listed in the NYC is vital. The assumption that procedural grounds for refusal of enforcement listed in NYC Article V (1) are covered by public policy would challenge the reasoning behind the separation of the two paragraphs under the above Article. What would be the point of listing procedural defects if they were to become embodied in public policy? As elements of public policy, they would be taken into account by the court ex officio, contradicting the general rule of NYC Article V (1). Furthermore, how does one reconcile the court acting ex officio in relation to procedural public policy with the burden of proof of procedural grounds lying on a party?

These concerns prove that procedural public policy and procedural defences under NYC Article V (1) should be separated. It was intended by the authors of the NYC that one group of grounds should be taken into

118 A. Ryabinin, Procedural Public Policy in Regard to the Enforcement and Recognition of Foreign Arbitral Awards, L.L.M. Short Thesis, Central European University, 2009, pp. 23-4.

119 Cf. M. Kurkela and S. Turunen, Due Process in International Commercial Arbitration, OUP, $1^{\text {st }}$ ed., Oxford 2004, p.185. 
account on the party's motion and another ex officio. The latter, including arbitrability and public policy, protects the vital interests of a state by preserving its legal system against prejudicial foreign norms and values. On the other hand, procedural grounds listed in NYC Article V (1) are focused on the parties' interests. They aim to ensure that procedural rights and guarantees of the parties to arbitration proceedings are respected.

However, the concept of separability is not absolute. Radical and complete separability could amount to a lack of powers on the part of the state courts to block ex officio the existence of foreign awards offending the state's legal system. Public policy, instead of being a shield against unwanted solutions, would become a worthless tool, failing to meet the goals for which it was intended. Nonetheless, any exceptions to the concept of separability have to be construed restrictively. The court is allowed to take procedural defects into account on its own motion if they constitute egregious violations of fundamental norms or values. These are of such a character that permitting the existence of arbitral awards burdened with such violations would damage the integrity of the judicial process and the basic sense of justice. Only applying the public policy exception ex officio can protect legal systems against the prejudicial influence of foreign arbitral awards; however, the analysis of the application of public policy has to be performed from the state's perspective.

\section{Bibliography}

J. van den Berg, Distinction Domestic-International Public Policy, [in:] 'New York Convention Consolidated Commentary Cases,' ICCA Yearbook, 1996, vol. XXI.

J. van den Berg, Refusals of Enforcement under the New York Convention of 1958: the Unfortunate Few, [in:] 'Arbitration in the Next Decade,' ICC Bulletin, Special Supplement 1999.

N. Blackaby et al. (eds.), Redfern and Hunter on International Arbitration, Oxford University Press, $5^{\text {th }}$ ed., Oxford 2009.

G.B. Born, International Commercial Arbitration, Wolters Kluwer, the Netherlands 2009.

Ch. Brunner, Procedural Public Policy as a Ground for Setting Aside International Arbitral Awards. Comments on the Swiss Federal Supreme Court's Decision of 28 April 2000 (Egemetal v. Fuchs; ATF 126 III 249), 'ASA Bulletin' 2000, vol. 18 , no 3 .

M.A. Buchanan, Public Policy and International Commercial Arbitration, 'American Business Law Journal' 1988, vol. 26. 
A. Chong, Transnational public policy in civil and commercial matters, 'Law Quarterly Review' 2012, vol. 128.

D.F.Donovan, International Commercial Arbitration and Public Policy, 'N.Y.U. Journal of International Law and Politics' 1994-1995, vol. 27.

J.D. Fry, Désordre Public International under the New York Convention: Wither Truly International Public Policy, 'Chinese Journal of International Law' 2009, vol. 8 , no 1 .

E. Gaillard and J. Savage, Part 6: Chapter I - French Law, [in:] Emmanuel Gaillard and John Savage (eds.), 'Fouchard Gaillard Goldman on International Commercial Arbitration,' Kluwer Law International, the Netherlands 1999.

B. Hanotiau and Olivier Caprasse, Arbitrability, Due Process, and Public Policy under Article V of the New York Convention, 'Journal of International Arbitration' 2008, vol. 25.

A. Jana, A. Armer, and J. Klein Kranenberg, Article V(1)(b), [in:] Herbert Kronke et al. (eds.), 'Recognition and Enforcement of Foreign Arbitral Awards. A Global Commentary on The New York Convention,' Wolters Kluwer, the Netherlands 2010.

M. Kurkela and S. Turunen, Due Process in International Commercial Arbitration, OUP, $1^{\text {st }}$ ed., Oxford 2004.

P. Lalive, Transnational (or Truly International) Public Policy, [in:] Pieter Sanders (ed.), 'Comparative Arbitration Practice and Public Policy in Arbitration,' ICCA Congress Series, 1986.

W. Ma, Recommendations on public policy in the enforcement of arbitral awards, 'Arbitration' 2009, vol. 75, no 1.

A.G. Maurer, The Public Policy Exception under the New York Convention. History, Interpretation, and Application, Juris, revised ed., New York 2013.

P. Mayer and A. Sheppard, Final ILA Report on Public Policy as a Bar to Enforcement of International Arbitral Awards, Report presented at International Law Association New Delhi Conference Committee on International Commercial Arbitration, New Delhi 2002.

L. Mistelis, "Keeping the Unruly Horse in Control" or Public Policy as a Bar to Enforcement of (Foreign) Arbitral Awards, 'International Law FORUM du droit international' 2000, vol. 2.

P. Nacimiento, Article V(1)(d), [in:] Herbert Kronke et al. (eds.), 'Recognition and Enforcement of Foreign Arbitral Awards. A Global Commentary on The New York Convention,' Wolters Kluwer, the Netherlands 2010.

D. Otto and O. Elwan, Article V(2) [in:] Reinmar Wolff (ed.), 'New York Convention on the Recognition and Enforcement of Foreign Arbitral Awards of 10 June 1958. Commentary,' C.H. Beck, Freiburg 2012.

L. Reed and J. Freda, Narrow Exceptions: A Review of Recent U.S. Precedent Regarding the Due Process and Public Policy Defenses of the New York Convention, 'Journal of International Arbitration' 2008, vol. 25, no 6. 
M. Rubino-Sammartano, International Arbitration Law and Practice, Kluwer Law International, $2^{\text {nd }}$ revised ed., the Netherlands 2001.

A. Ryabinin, Procedural Public Policy in Regard to the Enforcement and Recognition of Foreign Arbitral Awards, L.L.M. Short Thesis, Central European University, 2009.

H. Sikiric, Arbitration and Public Policy: Arbitration Proceedings and Public Policy, 'Croatian Arbitration Yearbook' 2000, vol. 7.

R. Wolff, Article V (2)(b), [in:] Reinmar Wolff (ed.), 'New York Convention on the Recognition and Enforcement of Foreign Arbitral Awards of 10 June 1958. Commentary,' C.H. Beck, Freiburg 2012. 